Article

\title{
Preparation of a New Type of Cemented Paste Backfill with an Alkali-Activated Silica Fume and Slag Composite Binder
}

\author{
Qi Sun ${ }^{1}$, Tianlong $\mathrm{Li}^{1}$ and Bing Liang ${ }^{2, *}$ \\ 1 School of Civil Engineering, Liaoning Technical University, Fuxin, Liaoning Province 123000, China; \\ sunqi@lntu.edu.cn (Q.S.); 471820438@stu.Intu.edu.cn (T.L.) \\ 2 School of Mechanics and Engineering, Liaoning Technical University, Fuxin, Liaoning Province 123000, China \\ * Correspondence: liangbing@lntu.edu.cn
}

Received: 18 December 2019; Accepted: 7 January 2020; Published: 13 January 2020

check for updates

\begin{abstract}
A new type of cemented paste backfill (CPB) was prepared using sodium hydroxide $(\mathrm{NaOH})$ as the activator, slag and silica fume (SF) as the binder, and tailings as the aggregate. The effects of proportion of replacement of $0 \%, 5 \%, 10 \%, 15 \%$, and $20 \%$ silica fume on the properties of CPB were studied. The strength formation mechanism of CPB was explored through a combination of scanning electron microscopy (SEM), energy dispersive spectrometry (EDS), and Fourier transform infrared (FTIR) spectroscopy. The SEM images were analyzed by IMAGE J software, and the porosity of $\mathrm{CPB}$ with different silica fume contents was obtained. The results show that as the amount of silica fume increases, the unconfined compressive strength (UCS) increases first and then decreases. When the amount of silica fume was approximately 5\%, CPB with a larger UCS can be obtained. When the silica fume content increased from $0 \%$ to $5 \%$, because silica fume has good activity and small particles, more calcium silicate hydrate (C-S-H) gels and $\mathrm{Mg}-\mathrm{Al}$ type layered double hydrotalcites (LDHs) were generated in $\mathrm{CPB}$, which made it denser and improved its strength compared with the non-silica fume group. C-S-H gels were the main source of CPB strength. With a further increase in the amount of silica fume, thaumasite produced inside of $\mathrm{CPB}$, reducing the content of C-S-H gels. Moreover, due to the expansion of thaumasite, it is easy to generate a large number of micro cracks in $\mathrm{CPB}$, which weakens the strength of $\mathrm{CPB}$.
\end{abstract}

Keywords: cemented paste backfill; alkali-activated silica fume and slag composite binder; strength formation mechanism; microstructure

\section{Introduction}

Tailings are solid waste formed by the beneficiation of metal minerals. According to statistics, the global average annual tailings output exceeds 10 billion tons and will continue to grow in the future [1,2]. The tailings discharged from a concentrator are often stacked into tailings dams. Accidents caused by dam breaks in tailings dams are common worldwide, and untreated tailings containing heavy metals that can easily contaminate land resources and groundwater resources, cause atmospheric pollution and endanger human health [3-5]. These issues have led many countries to undertake enormous fiscal expenditures to manage idle tailings [6]. Using tailings to prepare cemented paste backfill (CPB) and filling it into a mined-out area is not only conducive to controlling mining subsidence $[7,8]$ but also avoids geological disasters and environmental pollution caused by tailings dam instability, making it a green and sustainable method $[9,10]$. As a by-product of the metallurgical industry, silica fume (SF) and slag have pozzolanic activity. Therefore, alkali activation is used to stimulate the activity of silica fume and slag as a composite binder, and tailings are used as an aggregate to prepare a new type of environmentally friendly CPB is of great significance. 
In recent years, scholars have conducted in-depth research on the material composition and mechanical properties of CPB. Chen et al. [11,12] innovatively designed a large-scale similar stope model (SSM), tested the unconfined compressive strength (UCS) regularity of CPB at different locations, analyzed the mechanism, and concluded that the UCS reached a maximum at $60 \%$ of the SSM. CPB was prepared using phosphogypsum and building demolition waste to achieve clean production. Cao et al. [13-15] studied the effect of structural factors on the UCS of cemented tailings backfill (CTB), and considered the effects of different fiber additions on the strength and toughness of CTB. The UCS of CTB was higher with polypropylene fiber than with other fibers, and glass fiber had the best performance in terms of toughness. The change in the peak compressive strength of CTB at different loading rates was studied, showing a power function relationship. Qi et al. [16-18] proposed an intelligent method for predicting the UCS of $\mathrm{CPB}$, constructed a constitutive model and a strength prediction model for $\mathrm{CPB}$, and analyzed the hydration reaction mechanism of cement in $\mathrm{CPB}$. Liu et al. [19-21] studied the early hydration heat, hydration mechanism, and kinetic parameters of CPB by isothermal calorimetry, focused on the effect of the tailings-cement ratio (TCR) on hydration heat, and established a prediction model for paste composition and rheological properties. A negative exponential relationship between the porosity of the CPB and UCS was also proposed. Zhang et al. [22] prepared a cement paste containing copper tailings (CPCT) and studied the effects of the copper tailings dosage and curing age on the porosity of the slurry; they concluded that the microstructure became increasingly compact with increasing age and copper tailings consumption. Wu et al. [23,24] prepared cemented coal gangue-fly ash backfill (CGFB) using coal gangue, fly ash (FA) and ordinary Portland cement (OPC) as constituent materials; they analyzed the effect mechanism of multi-field coupling on the performance of CGFB and concluded that increasing the OPC/FA ratio and curing temperature could accelerate the hydration reaction and obtain higher compressive strength. Zhao et al. [25] used Portland cement (PC) and FA as a binder to study the law of CPB strength development and local strain and noted that $4 \%$ PC $+3 \%$ FA can simultaneously meet the minimum thresholds and requirements for mining stability. Su et al. [26] prepared CPB from cement and lead-zinc tailings and used the dynamic, static, and toxic leaching method to control metal elements by adding $2 \mathrm{mg} / \mathrm{L}$ polyaluminium sulfate (PAS).

Some scholars have also studied the application of alkali-activated binder in CPB. Sun et al. [27] prepared a geopolymer cemented coal gangue-fly ash backfill (GCGFB) using alkali-activated fly ash as a binder. The fracture evolution and deformation of GCGFB were observed using the digital speckle correlation method (DSCM). He et al. [28] studied the use of lithium slag and FA to prepare a binder and mixed it with tailings to prepare cemented fine tailings backfill (CFTB); they obtained the optimal ratio of CFTB and analyzed the strength formation mechanism. Katpady et al. [29] prepared a geopolymer using shirasu as an aluminosilicate, sodium hydroxide and water glass as an alkali activator, and slag as an additive, and they concluded that the UCS and acid resistance of the specimens were significantly improved with the addition of slag compared with no slag addition. Feng et al. [30,31] used mechanical activation and the incorporation of calcium oxide to improve the pozzolanic activity of granular copper slag (GCS); they also prepared a binder, as well as a suitable binder for formulating CPB. Jiang et al. [32,33] studied the early strength and working characteristics of CPB using alkali-activated slag as a binder; they also studied the change in yield stress of CPB under different low temperatures and time conditions. Cihangir et al. [34,35] comparatively analyzed the mechanical properties of samples using full tailings (FT) and deslimed sulphide-rich tailings (DT) as aggregates and alkali slag as a binder and noted that samples with DT had better performance than those with FT. In addition, $\mathrm{CPB}$ with different types of binders and different amounts of binder was prepared using cement and alkali-activated blast furnace slag. It was concluded that the performance of alkali-activated blast furnace slag as the binder is superior to that of cement in both the short and long term. Qiu et al. [36] studied the effects of different amounts of FA and blast furnace slag (BFS) and the amount of alkali used on the properties of the FA/BFS base polymer; they concluded that after increasing the amount of 
slag and the amount of alkali, the compressive strength of the slag increased, but there was a certain loss in slump.

Some scholars have investigated the use of alkali-activated slag and silica fume to prepare concrete and mortar, Collins et al. [37] used condensed silica fume to partially replace slag in the alkali-activated slag binder system, found that the strength and the water demand were significantly increased. Rostami et al. [38] mixed the silica fume in alkali-activated slag concrete, studied the strength and impermeability of concrete under different silica fume proportions of replacement and the effects on concrete under different curing conditions. Ramezanianpour et al. [39] used $\mathrm{NaOH}, \mathrm{KOH}, \mathrm{Na}_{2} \mathrm{SiO}_{3}$, etc. as stimulants and used different doses of nanosilica and silica fume to replace slag to prepare mortar. Rashad et al. [40] used sodium silicate to activate slag/silica fume pastes, and compared its compressive strength and thermal shock resistance at different high temperatures.

These studies used a variety of solid wastes to prepare $\mathrm{CPB}$ and examined the CPB mechanical properties. The use of alkali-activated slag as a binder to prepare $\mathrm{CPB}$ has achieved certain results. Some scholars have replaced silica fume with slag in the alkali-activated slag system to prepare binder and applied it to the preparation of concrete or mortar. However, no research has been reported on the preparation of CPB with slag and silica fume as the binder. Silica fume has good activity and small particle size. The addition of silica fume to alkali-activated CPB may improve its performance; therefore, further research is necessary.

In this paper, alkali-activated slag and silica fume were used as binders and tailings were used as aggregates to prepare a new CPB to explore the influence of the proportion of slag and silica fume on the UCS of CPB. The evolution mechanism of CPB strength was analyzed by scanning electron microscopy (SEM), energy dispersive spectrometry (EDS), and Fourier transform infrared (FTIR) spectroscopy.

\section{Materials and Methods}

\subsection{Materials}

The main binder for this study was S95 fine slag powder produced by Shandong Kangjing New Material Technology Co., Ltd. China, and silica fume was produced by Luoyang Yumin Micro Silica Fume Co., Ltd. China. The specific surface area of the slag and silica fume was $397.6 \mathrm{~m}^{2} / \mathrm{kg}$ and $414.3 \mathrm{~m}^{2} / \mathrm{kg}$. The aggregate is tailings taken from the Baoshan Iron Mine Concentrator in Anshan City, Liaoning Province, China. The particle size distribution of tailings and binders were characterized by BT-2003 laser particle size analyzer (Dandong Bettersize Instrument Co., Ltd., China) as shown in Figure 1. According to the Figure 1, tailings can be determined as fine aggregate. The maximum aggregate size was $398.2 \mu \mathrm{m}$. The specific surface area of the tailings was $231.3 \mathrm{~m}^{2} / \mathrm{kg}$. The bulk density of the aggregate was $1752.2 \mathrm{~kg} / \mathrm{m}^{3}$. The chemical composition of the slag, silica fume, and tailings was determined using a Shimadzu XRF1800 spectrometer. The specific chemical compositions are shown in Table 1. The mineral composition of tailings was measured by $X$-ray diffraction (XRD). XRD tests were conducted using a D8 ADVANCE X-ray diffractometer. According to XRD pattern shown in Figure 2, the mineral components of tailings mainly include mineral components such as quartz, chlorite-serpentine, muscovite, and anorthite. 


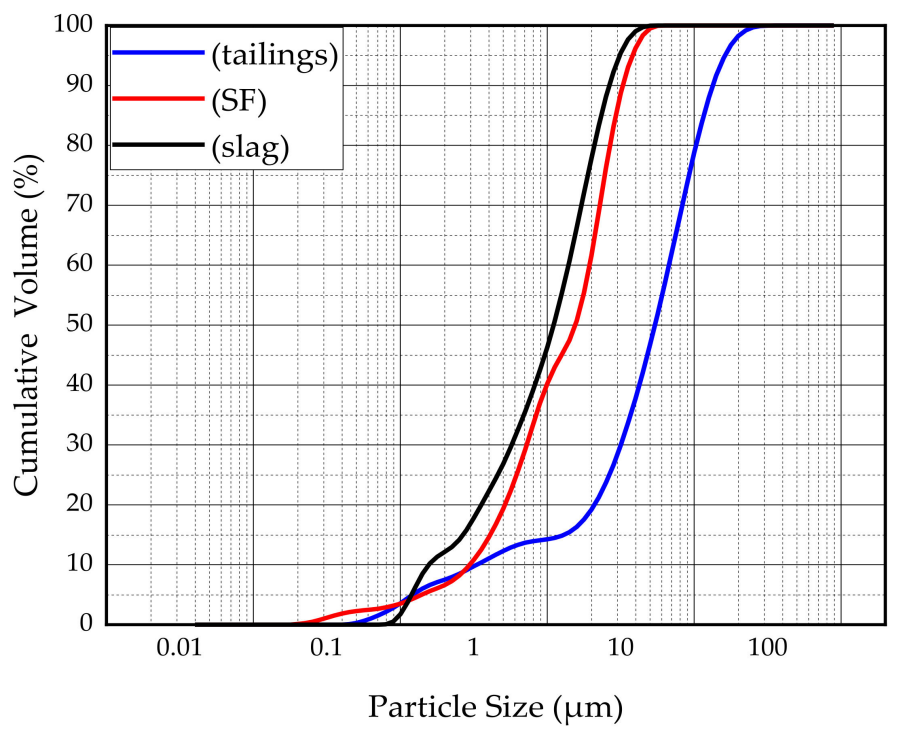

Figure 1. Particle size distribution of the tailings and binders.

The alkaline catalyst used in this study was a commercially available solid sample of sodium hydroxide from Liaoning Quanrui Reagent Factory with a purity of $96 \%$. Considering silica fume and slag as volcanic ash materials with high specific surface areas, to meet the mixture slump requirements and the $\mathrm{CPB}$ pumping requirements in the actual filling process, an appropriate amount of superplasticizer was used in the experiment to ensure that the slump was within the range of 150-200 mm. The superplasticizer was from Fuyang Chengnan Building Material Co., Ltd, China. It is a polycarboxylate-type superplasticizer in the form of a white powder, and the mixing water is tap water.

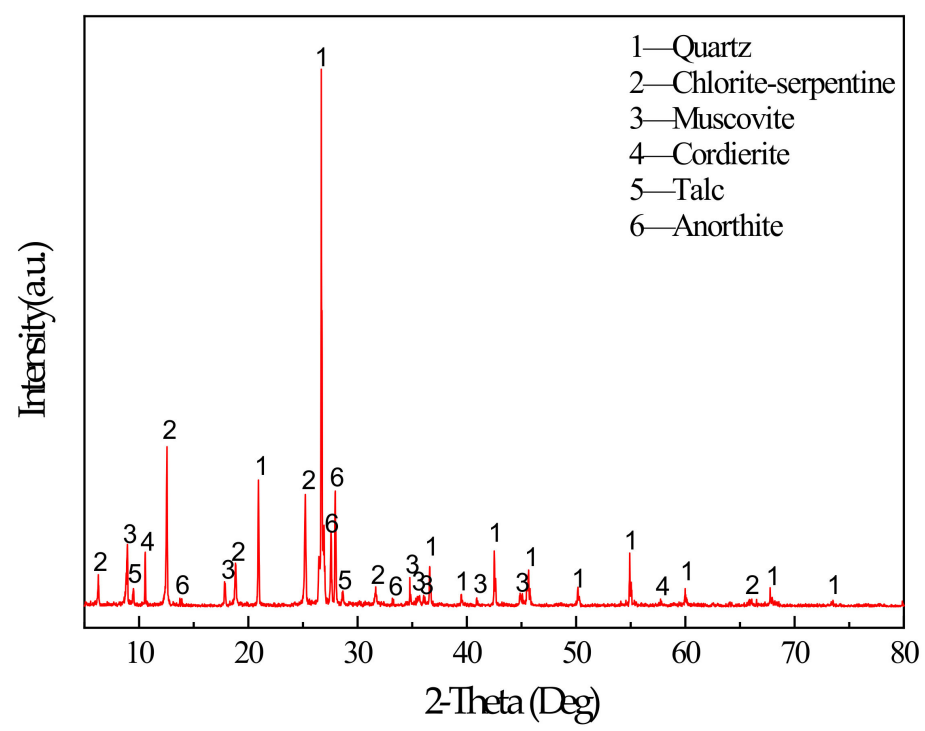

Figure 2. XRD pattern of tailings.

Table 1. Chemical composition of raw materials (wt. \%).

\begin{tabular}{ccccccccc}
\hline Materials & $\mathbf{C a o}$ & $\mathrm{Fe}_{\mathbf{2}} \mathbf{O}_{\mathbf{3}}$ & $\mathbf{S i O}_{\mathbf{2}}$ & $\mathbf{A l}_{\mathbf{2}} \mathbf{O}_{\mathbf{3}}$ & $\mathbf{M g O}$ & $\mathbf{N a}_{\mathbf{2}} \mathbf{O}$ & $\mathbf{K}_{\mathbf{2}} \mathbf{O}$ & $\mathbf{S O}_{\mathbf{3}}$ \\
\hline Slag & 40.75 & 0.55 & 27.51 & 16.20 & 7.77 & 0.26 & 0.25 & 2.91 \\
SF & 1.70 & 0.65 & 95.59 & - & 0.22 & - & 0.34 & 0.69 \\
Tailings & 3.06 & 35.49 & 40.62 & 10.81 & 6.60 & - & 1.03 & 0.47 \\
\hline
\end{tabular}




\subsection{Test Methods}

The mixture proportion is shown in Table 2. The proportion of silica fume in the binder was $0 \%, 5 \%, 10 \%, 15 \%$, and $20 \%$, corresponding to the SF0-SF20 group. After a large number of previous attempts, the experimental parameters were determined to be a water-binder ratio of 2.1 and an aggregate-binder ratio of 7 , with an alkali content of $4 \%$ by binder mass (alkali content was $3.1 \%$ if calculated in terms of $\mathrm{Na}_{2} \mathrm{O}$ ). Binder content was $9.86 \%$ of the total mass. The dosage of superplasticizer in each group is shown in Table 2. The mixing water used in the experiment consisted of two parts: one was used to dissolve the solid particles of $\mathrm{NaOH}$ and the superplasticizer, and the other was used to rinse the solution remaining in the glass beaker during the process of dumping the solution. To better dissolve the $\mathrm{NaOH}$ solid and superplasticizer, a certain amount of water was first added until the $\mathrm{NaOH}$ solid was fully mixed and dissolved. The superplasticizer was then added under continuous stirring until it was homogeneous, and the solution was left at room temperature for $10 \mathrm{~min}$ for further processing. After weighing the binder and aggregates used in the experiment, the aggregates were placed in a UJZ-15 mortar mixer manufactured by Shanghai Luda Experimental Instrument Co., Ltd., and stirred for $3 \mathrm{~min}$. Then, the slag and silica fume were poured into the mixer in three portions and stirred for $3 \mathrm{~min}$ to ensure material homogeneity in the mixer. Finally, the pre-configured solution was poured into the mortar mixer and stirred well for $4 \mathrm{~min}$. The slump test was performed immediately after the stirring was completed. The slump test results of SF0-SF20 group were: $195 \mathrm{~mm}, 180 \mathrm{~mm}$, $170 \mathrm{~mm}, 175 \mathrm{~mm}$, and $190 \mathrm{~mm}$. The fresh mixture was poured into a cylindrical mold with a diameter of $50 \mathrm{~mm}$ and a height of $100 \mathrm{~mm}$. Three test specimens were prepared at each age for UCS testing. All molds containing the mixture were placed on a shaking table and shaken for 40 seconds. The mold containing the mixture was sealed and placed in a concrete standard curing box in which the temperature was controlled at $20( \pm 1)^{\circ} \mathrm{C}$, and the humidity was controlled at $\geq 96 \%$ for curing. Model of concrete standard curing box is $\mathrm{YH}-40 \mathrm{~B}$. After one day of curing, the CPB molds were demolded and keep the samples in the above environment. After 28 days of curing, uniaxial compression experiments, SEM, EDS, and FTIR experiments were performed. Uniaxial compression experiments were performed using a universal testing machine. A HITACHI S-3400N scanning electron microscope was used for SEM and EDS analysis at a voltage of $20.0 \mathrm{kV}$. A Nicolet iS50 Fourier infrared spectrometer was used for characterization.

Table 2. Details of the mixture proportions.

\begin{tabular}{cccccc}
\hline \multirow{2}{*}{ MIX ID } & \multicolumn{2}{c}{ Binder Proportion (wt \%) } & \multicolumn{2}{c}{$\begin{array}{c}\text { Alkaline and Admixture (by } \\
\text { Binder Mass \%) }\end{array}$} & \multirow{2}{*}{ Water-Binder Ratio } \\
\cline { 2 - 5 } & Slag & SF & Alkaline & Super Plasticizer & \\
\hline SF0 & 100 & 0 & 4 & 0.2 & 2.1 \\
SF5 & 95 & 5 & 4 & 0.4 & 2.1 \\
SF10 & 90 & 10 & 4 & 0.6 & 2.1 \\
SF15 & 85 & 15 & 4 & 0.6 & 2.1 \\
SF20 & 80 & 20 & 4 & 1.0 & 2.1 \\
\hline
\end{tabular}

\section{Results and Discussion}

\subsection{Unconfined Compressive Strength}

The UCS test results of specimens with different curing ages are shown in Figure 3. From the 3-day UCS, compared to the non-silica fume group, the increase in strength of the silica fume group was not significant because $\mathrm{CPB}$ had a slower reaction rate and fewer hydration products generated within 3 days of curing. After 7 days of curing, the UCS of each group began to grow rapidly because CPB had a certain early strength and reached its peak after 28 days. From the test results, it is clear that for the SF5 group, in which the slag and silica fume account for $95 \%$ and $5 \%$ of the binder, respectively, the UCS of each age was better than that of the other groups. Compared with the SF0 group, the 
SF5 group introduced a silicon source due to the addition of silica fume, and the slag in the mixture provided a large amount of calcium and aluminum. Under the action of the alkali-stimulated catalyst, a large amount of $\mathrm{C}-\mathrm{S}-\mathrm{H}$ gels and $\mathrm{Mg}-\mathrm{Al}$ type LDHs were generated, which became the main source of CPB strength. These generated gels compress the pores, while at the same time, because the silica fume particles are very small, they have a good filling effect on the pores and make the microstructure denser. Therefore, the UCS was higher in the SF5 group than in the SF0 group. With an increase in the amount of silica fume, UCS showed a trend of increasing first and then decreasing, which is similar to the experimental results of silica fume mixed with concrete presented by Wetzel et al. [41] and Alanazi et al. [42]. It is worth noting that for the SF15 and SF20 groups, the UCS value of all curing ages was significantly lower than that of SF0, which indicates that the more silica fume that is used, the easier it is to decrease the UCS.

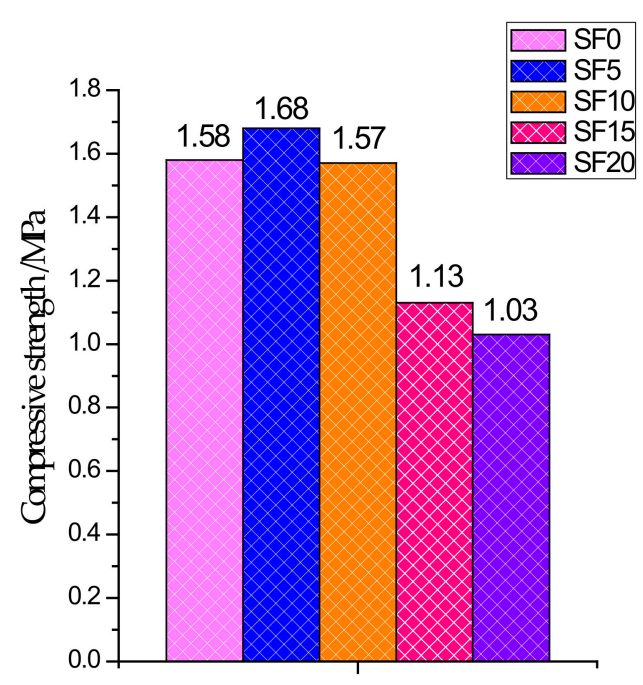

(a)

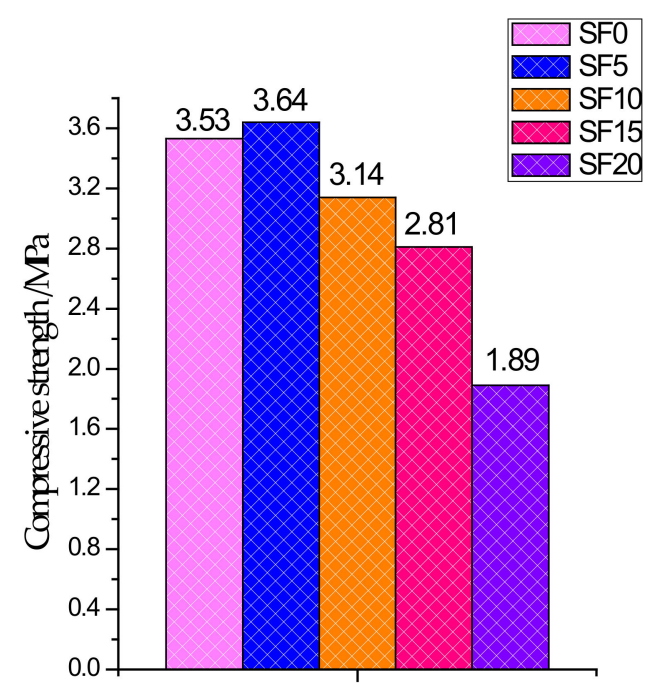

(c)

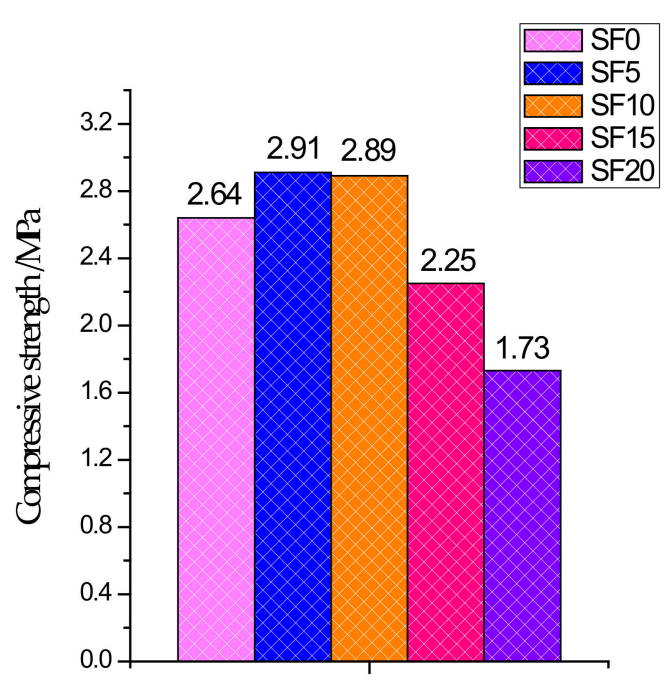

(b)

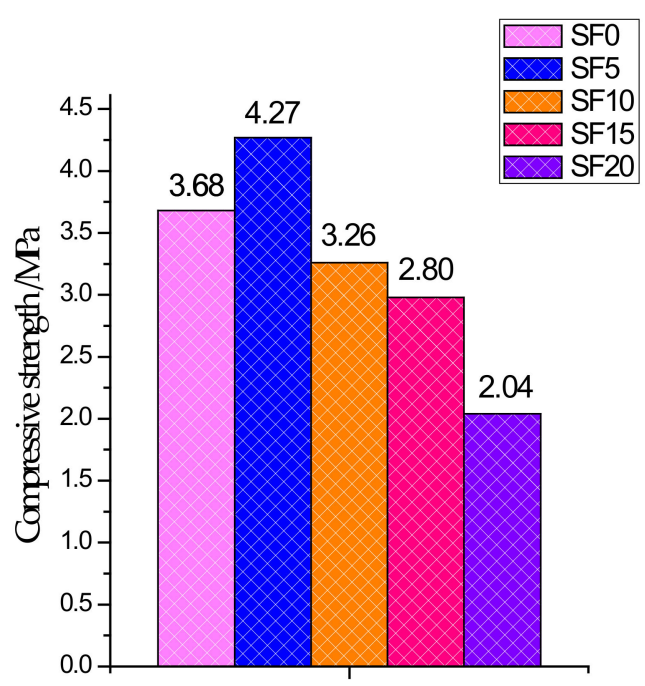

(d)

Figure 3. Compressive strength of different groups: (a) 3 days; (b) 7 days; (c) 14 days; and (d) 28 days. 


\subsection{Microstructural Analysis}

In this experiment, specimens with a curing age of 28 days were selected to observe their microstructure. The SEM micrograph of the hydration products of the SF0 group is shown in Figure 4a. From Figure $4 \mathrm{a}$, a large amount of flocculent matter could be observed. According to the EDS spectrum of Figure 5, there were high contents of $\mathrm{O}, \mathrm{Mg}, \mathrm{Al}, \mathrm{Si}$, and $\mathrm{Ca}$ elements. It is presumed that the hydration products of slag are $\mathrm{C}-\mathrm{S}-\mathrm{H}$ and $\mathrm{Mg}-\mathrm{Al}$ type LDHs, which are closely intertwined. This is similar to the findings of [43]. When slag contains $\mathrm{MgO}, \mathrm{C}-\mathrm{S}-\mathrm{H}$ gel, and $\mathrm{Mg}-\mathrm{Al}$ type LDHs $\left(\mathrm{Mg}_{6} \mathrm{Al}_{2} \mathrm{CO}_{3}(\mathrm{OH})_{16} \cdot 4\left(\mathrm{H}_{2} \mathrm{O}\right)\right)$ are the main hydration products of slag. When they are tightly intertwined, $\mathrm{O}, \mathrm{Mg}, \mathrm{Al}, \mathrm{Si}$, and $\mathrm{Ca}$ elements coexist in a large amount in EDS. At the same time, white flocculent precipitates could also be observed. According to the EDS spectrum of Figure 6, there were high contents of $\mathrm{O}, \mathrm{Si}$, and $\mathrm{Ca}$ elements, while $\mathrm{Na}$ accounted for only $1.07 \%$, and Al elements accounted for $3.08 \%$. It was confirmed that the hydration product was the C-S-H gel. Many different-sized pores could be observed in the microstructure, which is one of the reasons why the compressive strength of this group is lower than that of SF5. An SEM micrograph of the hydration products of the SF5 group is shown in Figure $4 \mathrm{~b}$. Compared with the SF0 group, this group has a dense microstructure with few visible pores and very small pores. Analogous to the SEM image of the SF0 group, Mg-Al type LDHs and a white flocculent precipitate of C-S-H gels can also be observed, and these two hydration products were present in significantly higher amounts in the SF5 group than in the SF0 group. The calcium and aluminum elements contained in slag with the silicon elements contained in silica fume were better fused in SF5 than in SF0 to generate corresponding hydration products. The reaction equations [44] involved are shown below.

$$
\mathrm{SiO}_{2}+\mathrm{Ca}(\mathrm{OH})_{2}+\mathrm{H}_{2} \mathrm{O} \rightarrow \mathrm{CaO} \cdot \mathrm{SiO}_{2} \cdot \mathrm{xH}_{2} \mathrm{O}
$$

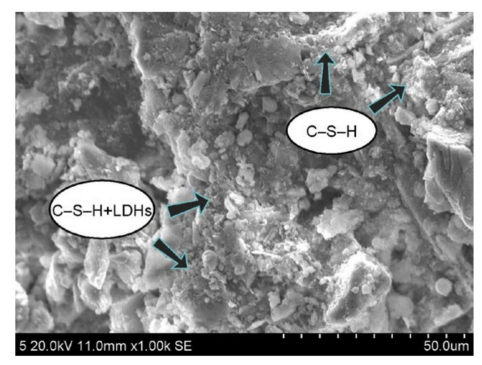

(a)

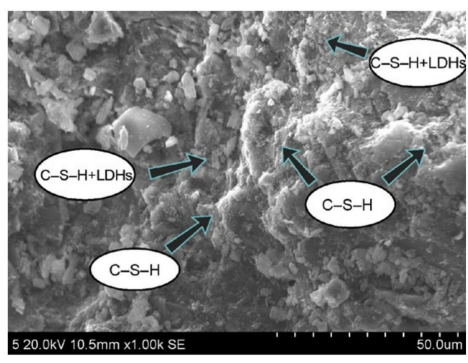

(b)

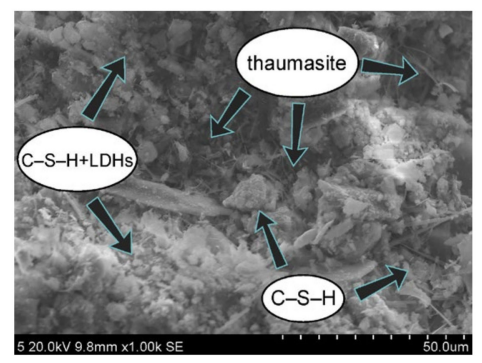

(c)

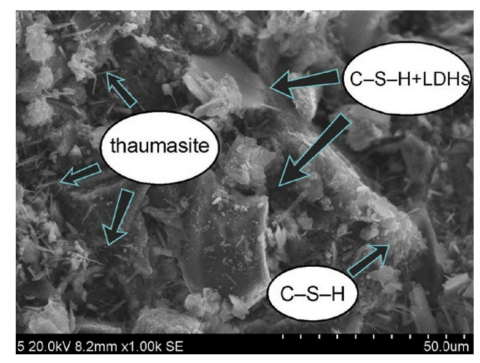

(d)

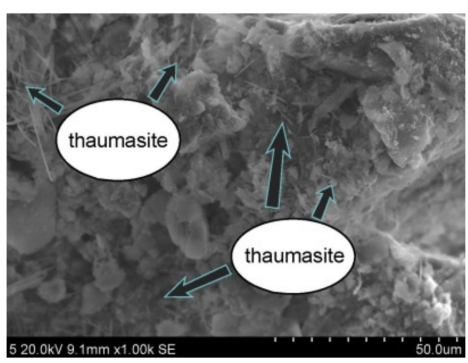

(e)

Figure 4. Micromorphology of cemented paste backfill (CPB) samples at 28 days: (a) SF0; (b) SF5; (c) SF10; (d) SF15; and (e) SF20. 


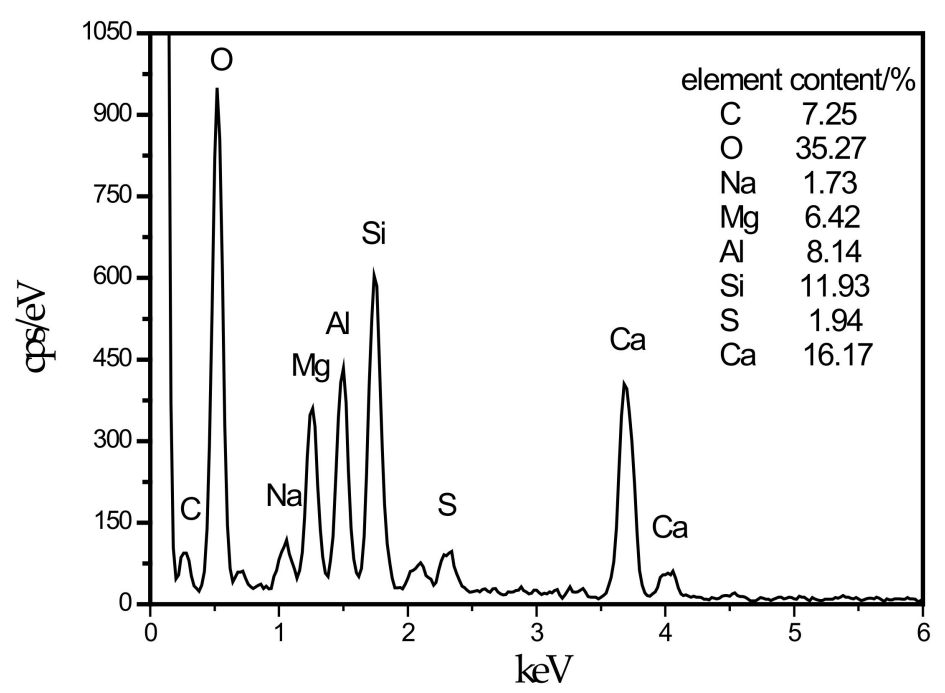

Figure 5. Energy dispersive spectrometry (EDS) energy spectrum of LDHs intimately intermix with the C-S-H.

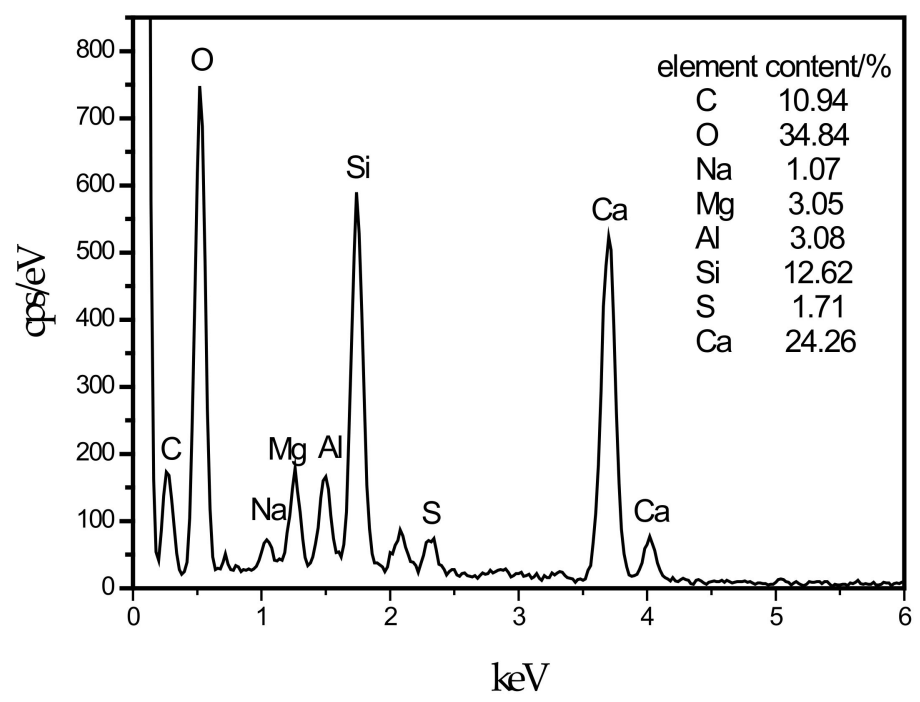

Figure 6. EDS energy spectrum of C-S-H.

An SEM image of the SF10 group is shown in Figure 4c. A small amount of fine needle-like hydration products can be observed. A small portion of these hydration products fills the pores, and most of the products adhere near the $\mathrm{C}-\mathrm{S}-\mathrm{H}$ gels. For the known hydration products in the concrete field, the fine needles are mainly ettringite and thaumasite, and their morphologies are very similar [45]. To discriminate whether this needle-like hydration product is ettringite or thaumasite, an analysis is shown in Figure 7. The EDS spectrum shows that $11.42 \%$ Si was present in the hydration product, and the other elements contained in thaumasite were reflected in the energy spectrum. It can be preliminarily speculated that the hydration product is thaumasite.

An SEM image of the SF15 group is shown in Figure 4d. The needle-like hydration products can be clearly observed, and layered substances appeared near these products. Haha et al. [43] indicated that the $\mathrm{Mg}$-Al type $\mathrm{LDHs}\left(\mathrm{Mg}_{6} \mathrm{Al}_{2} \mathrm{CO}_{3}(\mathrm{OH})_{16} \cdot 4\left(\mathrm{H}_{2} \mathrm{O}\right)\right)$ is a substance with a layered structure, and $\mathrm{C}-\mathrm{S}-\mathrm{H}$ is covered with LDHs. Therefore, the EDS energy spectrum (Figure 8) contains a large number of $\mathrm{O}, \mathrm{Mg}, \mathrm{Al}, \mathrm{Si}$, and $\mathrm{Ca}$ elements. At the same time, it can be observed that the number of $\mathrm{C}-\mathrm{S}-\mathrm{H}$ gels compared with those in Figure $4 \mathrm{c}$ was significantly reduced.

An SEM image of the SF20 group is shown in Figure 4e. From the figure, many needle-like hydration products could be seen, and a very small amount of C-S-H gel was observed. This is 
probably due to the large amount of $\mathrm{C}-\mathrm{S}-\mathrm{H}$ gel consumed by the reaction and the thaumasite formed on the surface of the remaining $\mathrm{C}-\mathrm{S}-\mathrm{H}$ gel.

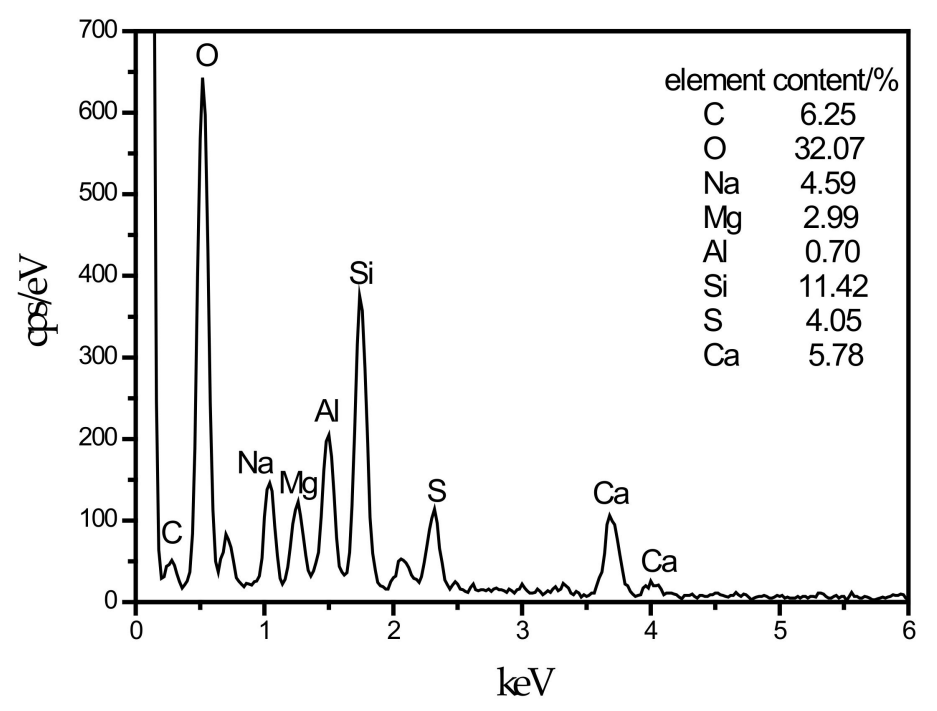

Figure 7. EDS energy spectrum of thaumasite.

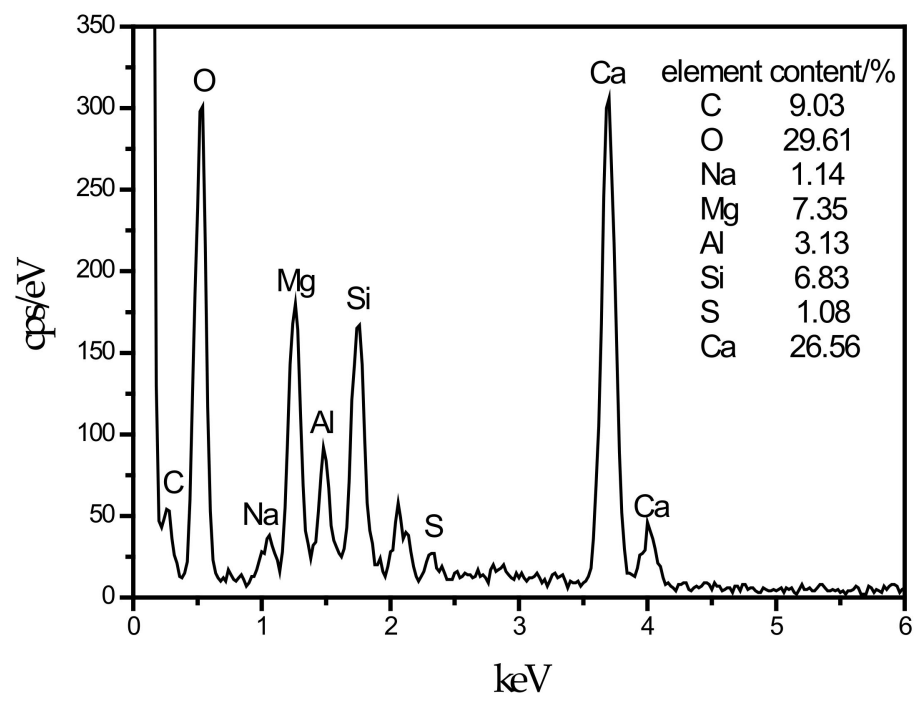

Figure 8. EDS energy spectrum of LDHs cover C-S-H.

\subsection{FTIR Spectral Analysis}

To further determine the needle-like hydration products appearing in the SEM picture, this study performed an FTIR test on the SF20 group cured for 28 days. The FTIR spectrum is shown in Figure 9. According to a report by Ma et al. [46], the main wavenumbers for distinguishing thaumasite are $673 \mathrm{~cm}^{-1}$ for $\mathrm{SiO}_{6}$ stretching, $1100 \mathrm{~cm}^{-1}$ for $\mathrm{SO}_{4}^{2-}$ stretching, $1400 \mathrm{~cm}^{-1}$ for $\mathrm{CO}_{3}^{2-}$ stretching, and $1650 \mathrm{~cm}^{-1}$ and $3600-3200 \mathrm{~cm}^{-1}$ for $\mathrm{H}_{2} \mathrm{O}$ bending and stretching, respectively. It can be observed from the spectrum that a peak exists at a wavenumber of $669.43 \mathrm{~cm}^{-1}$. By comparing and analyzing the known wavenumber, it can be determined that the peak corresponds to the $\mathrm{SiO}_{6}$ stretching vibration. The silicon and oxygen in thaumasite have been shown to exist in the 6-coordinated form [47], and ettringite does not contain this chemical bond. The peak at $1074.52 \mathrm{~cm}^{-1}$ and the corresponding peak at $1100 \mathrm{~cm}^{-1}$ can be determined as $\mathrm{SO}_{4}^{2-}$ stretching. The peak at $1426 \mathrm{~cm}^{-1}$ corresponds to the $\mathrm{C}-\mathrm{O}$ bond stretching vibration, which is caused by the presence of $\mathrm{CO}_{3}^{2-}$. The peaks at $1633.03 \mathrm{~cm}^{-1}$ and $3407.91 \mathrm{~cm}^{-1}$ can be determined as the bending and stretching of $\mathrm{H}_{2} \mathrm{O}$, respectively. In contrast, a peak at $850 \mathrm{~cm}^{-1}$ for $\mathrm{AlO}_{6}$ is unique to ettringite but is not observed in the figure. Therefore, 
the needle-like hydration product can be determined as thaumasite. The main reason for the formation of thaumasite is that aluminate in slag reacts with the ferrite and sulfate in tailings to form ettringite, and calcium carbonate can form due to the reaction of calcium hydroxide with $\mathrm{CO}_{2}$ in solution or air. In this environment, the C-S-H gel reacts with ettringite, and the silicon element in the C-S-H gel continuously replaces the aluminum element in ettringite. With the progress of the reaction, ettringite is finally converted into thaumasite. In the SF5 group, no thaumasite was observed because the amount of silica fume was small, and this reaction was not sufficient to cause the above reaction. The reaction equation [48] involved is shown below.

$$
\begin{gathered}
\mathrm{Ca}_{6}\left[\mathrm{Al}_{\mathrm{x}} \mathrm{Fe}_{(1-\mathrm{x})}(\mathrm{OH})_{6}\right]_{2}\left(\mathrm{SO}_{4}\right)_{3} \cdot 26 \mathrm{H}_{2} \mathrm{O}+\mathrm{Ca}_{3} \mathrm{Si}_{2} \mathrm{O}_{7} 3 \mathrm{H}_{2} \mathrm{O}+2 \mathrm{CaCO}_{3}+4 \mathrm{H}_{2} \mathrm{O} \\
\rightarrow \mathrm{Ca}_{6}\left[\mathrm{Si}(\mathrm{OH})_{6}\right]_{2}\left(\mathrm{CO}_{3}\right)_{2}\left(\mathrm{SO}_{4}\right)_{2} 24 \mathrm{H}_{2} \mathrm{O}+\mathrm{CaSO}_{4} 2 \mathrm{H}_{2} \mathrm{O}+2 \mathrm{xAl}(\mathrm{OH})_{3} \\
+2(1-\mathrm{x}) \mathrm{Fe}(\mathrm{OH})_{3}+4 \mathrm{Ca}(\mathrm{OH})_{2} \\
\mathrm{Ca}(\mathrm{OH})_{2}+\mathrm{CO}_{2} \rightarrow \mathrm{CaCO}_{3}+\mathrm{H}_{2} \mathrm{O}
\end{gathered}
$$

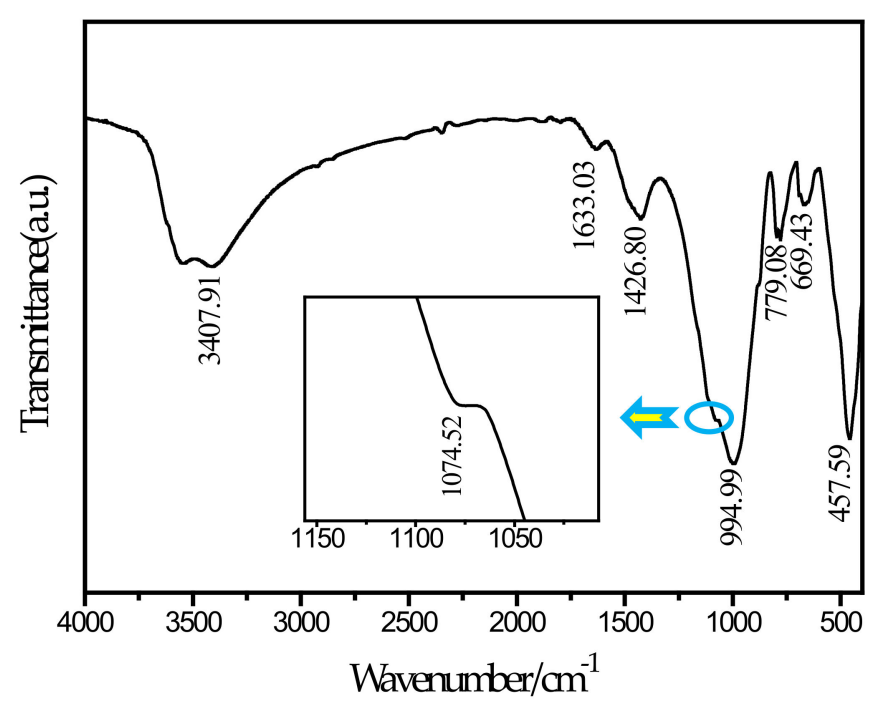

Figure 9. FTIR spectrum of SF20.

Thaumasite has been proven to be a swellable hydration product and easily cause micro-cracks in CPB [49]. With the increase of silica fume replacement proportion, the content of calcium element decrease, that is because the added silicon is not enough to produce more hydration products with the other elements, so the $\mathrm{C}-\mathrm{S}-\mathrm{H}$ gels generated during the same period are reduced. Meanwhile, $\mathrm{C}-\mathrm{S}-\mathrm{H}$ gels were the main source of CPB strength. Due to expansibility of thaumasite, a large number of micro-cracks were generated in the $\mathrm{CPB}$, leading to a decrease in the CPB strength. Therefore, the reduction of $\mathrm{C}-\mathrm{S}-\mathrm{H}$ gels and the appearance of thaumasite led to a decrease in CPB strength.

\subsection{Pore Structure Analysis}

In this paper, Image J software was used to analyze the pore structure on the basis of the SEM images of the specimens with a curing age of 28 days and a magnification of 1000 times of the different groups. A pore structure analysis diagram is shown in Figure 10. The pore analysis results are shown in Table 3. The black area in the picture corresponds to the pore structure, and the white areas are mainly the generated hydration products. From Figure 10a corresponding to the SF0 group, it can be understood that except for a small area of pores on the left side of the picture, most of the pore areas were not clustered but mostly existed in the form of small pores. Part of the hydration products was attached near the pores, and some pores were wrapped by the hydration products. As the curing time increases, the generated Mg-Al type LDHs and C-S-H gel began to fill the pores continuously, thus 
compressing the pores, making the microstructure more compact and reducing the porosity. The SF5 group is shown in Figure 10b. It is clear that the red area was smaller than the SF0 group. Not only did we not observe the pores that forming the area like the SF0 group, but the particle size of these small pores was also observed to be significantly smaller than those in the SF0 group. These small pores were distributed near the hydration products, indicating that compared with the SF0 group, the hydration reaction of the mixture in the SF5 group occurs more readily, leading to an increase in $\mathrm{Mg}-\mathrm{Al}$ type LDHs and C-S-H gel, and the degree of pore compression was higher than that in the SF0 group. During the UCS test, with increasing axial load, due to the small number of pores and the small pore volume, the load on the test specimen was uniform at levels approximately, so the specimen was subjected to more complete force during the entire uniaxial compression process and thus had a higher UCS value. From the test results, the porosity of the SF5 group was $18.38 \%$, which was significantly smaller than that of the SF0 group by $23.08 \%$. From the perspective of macro-mechanical properties, the UCS value of the SF5 group was greater than that of the SF0 group. The pore maps of the SF10, SF15, and SF20 groups are shown in Figure 10c-e, respectively. The porosity of the SF10, SF15, and SF20 groups was higher than that of the SF5 group. This may be due to the reduction of the C-S-H gels and the micro-cracks generated by thaumasite.

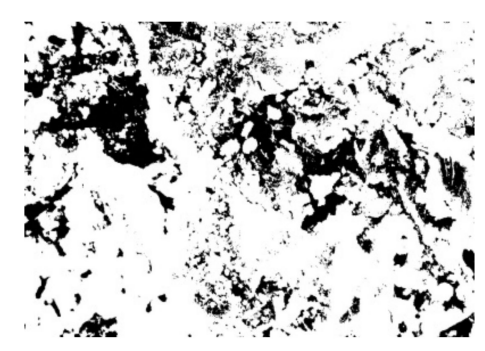

(a)

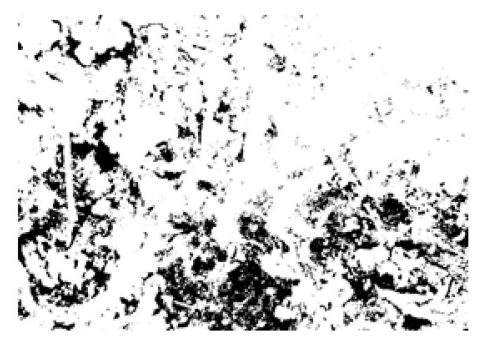

(b)

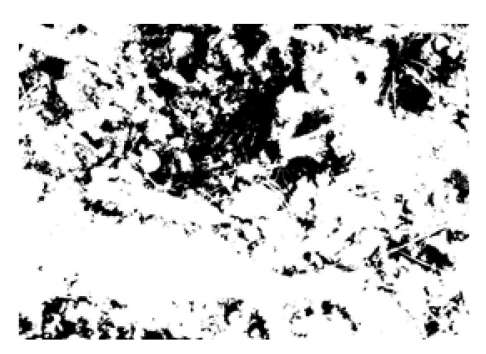

(c)

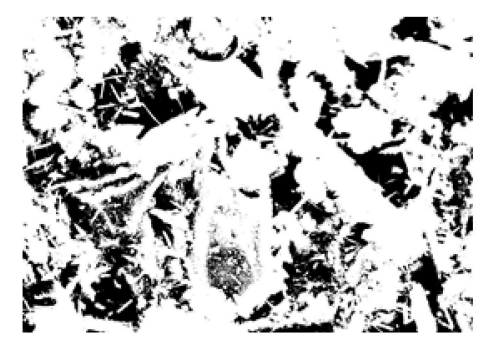

(d)

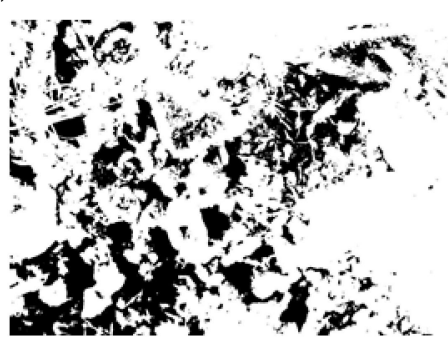

(e)

Figure 10. CPB pore structure analysis of different groups: (a) SF0; (b) SF5; (c) SF10; (d) SF15; and (e) SF20.

Table 3. Porosity of the CPB samples.

\begin{tabular}{cccccc}
\hline MIX ID & SF0 & SF5 & SF10 & SF15 & SF20 \\
\hline Porosity \% & 23.08 & 18.38 & 25.08 & 27.19 & 24.03 \\
\hline
\end{tabular}

\section{Conclusions}

1. With increasing silica fume, the UCS tended to increase first and then decrease. When the amount of silica fume was approximately $5 \%$, CPB with a larger UCS could be obtained.

2. When the amount of silica fume increased from $0 \%$ to $5 \%$, because silica fume had good activity and small particles, more $\mathrm{C}-\mathrm{S}-\mathrm{H}$ gels and $\mathrm{Mg}-\mathrm{Al}$ type $\mathrm{LDH}$ were produced in $\mathrm{CPB}$, and it became increasingly denser, thus increasing the $\mathrm{CPB}$ strength.

3. C-S-H gels were the main source of $\mathrm{CPB}$ strength. As the amount of silica fume gradually increased from $5 \%$ to $15 \%$, thaumasite gradually produced inside the $\mathrm{CPB}$, reducing the content 
of C-S-H gels. Due to the expansibility of thaumasite, a large number of micro-cracks were generated in the $\mathrm{CPB}$, leading to a decrease in the $\mathrm{CPB}$ strength.

Author Contributions: Data curation, B.L.; Formal analysis, B.L.; Investigation, T.L.; Writing—original draft, Q.S.; Writing-review and editing, Q.S. All authors have read and agreed to the published version of the manuscript.

Funding: The authors would like to acknowledge the National Natural Science Foundation of China (No. 51504125, 51574145), the Natural Science Foundation of Liaoning Province (2019-MS-158), and the Science and Technology Research Project of the Department of Education of Liaoning Province (LJ2017QL022).

Acknowledgments: The authors would like to thank AJE (www.aje.com) for editing the English language.

Conflicts of Interest: The authors declare no conflicts of interest

\section{References}

1. Wang, L.; Ji, B.; Hu, Y.; Liu, R.; Sun, W. A review on in situ phytoremediation of mine tailings. Chemosphere 2017, 184, 594-600. [CrossRef] [PubMed]

2. Adiansyah, J.S.; Rosano, M.; Vink, S.; Keir, G. A framework for a sustainable approach to mine tailings management: Disposal strategies. J. Clean. Prod. 2015, 108, 1050-1062. [CrossRef]

3. Qi, C.; Fourie, A. Cemented paste backfill for mineral tailings management: Review and future perspectives. Miner. Eng. 2019, 144, 106025. [CrossRef]

4. Edraki, M.; Baumgartl, T.; Manlapig, E.; Bradshaw, D.; Franks, D.M.; Moran, C.J. Designing mine tailings for better environmental, social and economic outcomes: A review of alternative approaches. J. Clean. Prod. 2014, 84, 411-420. [CrossRef]

5. Yin, S.; Wu, A.; Hu, K.; Wang, Y.; Zhang, Y. The effect of solid components on the rheological and mechanical properties of cemented paste backfill. Miner. Eng. 2012, 35, 61-66. [CrossRef]

6. Qi, C.; Chen, Q.; Fourie, A.; Tang, X.; Zhang, Q.; Dong, X.; Feng, Y. Constitutive modelling of cemented paste backfill: A data-mining approach. Constr. Build. Mater. 2019, 197, 262-270. [CrossRef]

7. Jiang, H.; Fall, M. Yield stress and strength of saline cemented tailings materials in sub-zero environments: Slag-paste backfill. J. Sustain. Cem.-Based Mater. 2017, 6, 314-331. [CrossRef]

8. Chen, X.; Shi, X.; Zhou, J.; Du, X.; Chen, Q.; Qiu, X. Effect of overflow tailings properties on cemented paste backfill. J. Environ. Manag. 2019, 235, 133-144. [CrossRef]

9. Lu, H.; Qi, C.; Li, C.; Gan, D.; Du, Y.; Li, S. A light barricade for tailings recycling as cemented paste backfill. J. Clean. Prod. 2019, 247, 119388. [CrossRef]

10. Yin, S.; Shao, Y.; Wu, A.; Wang, H.; Liu, X.; Wang, Y. A systematic review of paste technology in metal mines for cleaner production in China. J. Clean. Prod. 2020, 247, 119590. [CrossRef]

11. Chen, Q.; Zhang, Q.; Fourie, A.; Chen, X.; Qi, C. Experimental investigation on the strength characteristics of cement paste backfill in a similar stope model and its mechanism. Constr. Build. Mater. 2017, 154, 34-43. [CrossRef]

12. Chen, Q.; Zhang, Q.; Qi, C.; Fourie, A.; Xiao, C. Recycling phosphogypsum and construction demolition waste for cemented paste backfill and its environmental impact. J. Clean. Prod. 2018, 186, 418-429. [CrossRef]

13. Cao, S.; Song, W.; Yilmaz, E. Influence of structural factors on uniaxial compressive strength of cemented tailings backfill. Constr. Build. Mater. 2018, 174, 190-201. [CrossRef]

14. Cao, S.; Yilmaz, E.; Song, W. Fiber type effect on strength, toughness and microstructure of early age cemented tailings backfill. Constr. Build. Mater. 2019, 223, 44-54. [CrossRef]

15. Cao, S.; Yilmaz, E.; Song, W.; Yilmaz, E.; Xue, G. Loading rate effect on uniaxial compressive strength behavior and acoustic emission properties of cemented tailings backfill. Constr. Build. Mater. 2019, 213, 313-324. [CrossRef]

16. Qi, C.; Chen, Q.; Fourie, A.; Zhang, Q. An intelligent modelling framework for mechanical properties of cemented paste backfill. Miner. Eng. 2018, 123, 16-27. [CrossRef]

17. Qi, C.; Fourie, A.; Chen, Q. Neural network and particle swarm optimization for predicting the unconfined compressive strength of cemented paste backfill. Constr. Build. Mater. 2018, 159, 473-478. [CrossRef]

18. Qi, C.; Fourie, A.; Chen, Q.; Zhang, Q. A strength prediction model using artificial intelligence for recycling waste tailings as cemented paste backfill. J. Clean. Prod. 2018, 183, 566-578. [CrossRef] 
19. Liu, L.; Yang, P.; Qi, C.; Zhang, B.; Guo, L.; Song, K.-I. An experimental study on the early-age hydration kinetics of cemented paste backfill. Constr. Build. Mater. 2019, 212, 283-294. [CrossRef]

20. Liu, L.; Song, K.-I.; Lao, D.; Kwon, T.-H. Rheological properties of cemented tailing backfill and the construction of a prediction model. Materials 2015, 8, 2076-2092.

21. Liu, L.; Fang, Z.; Qi, C.; Zhang, B.; Guo, L.; Song, K.-I. Experimental investigation on the relationship between pore characteristics and unconfined compressive strength of cemented paste backfill. Constr. Build. Mater. 2018, 179, 254-264. [CrossRef]

22. Zhang, L.; Liu, S.; Song, D. Effect of the content of micro-active copper tailing on the strength and pore structure of cementitious materials. Materials 2019, 12, 1861. [CrossRef] [PubMed]

23. Wu, D.; Hou, Y.; Deng, T.; Chen, Y.; Zhao, X. Thermal, hydraulic and mechanical performances of cemented coal gangue-fly ash backfill. Int. J. Miner. Process. 2017, 162, 12-18. [CrossRef]

24. Wu, D.; Sun, G.; Liu, Y. Modeling the thermo-hydro-chemical behavior of cemented coal gangue-fly ash backfill. Constr. Build. Mater. 2016, 111, 522-528. [CrossRef]

25. Zhao, Y.; Taheri, A.; Soltani, A.; Karakus, M.; Deng, A. Strength development and strain localization behavior of cemented paste backfills using portland cement and fly ash. Materials 2019, 12, 3282. [CrossRef]

26. Su, Z.; Chen, Q.; Zhang, Q.; Zhang, D. Recycling lead-zinc tailings for cemented paste backfill and stabilisation of excessive metal. Minerals 2019, 9, 710. [CrossRef]

27. Sun, Q.; Cai, C.; Zhang, S.; Tian, S.; Li, B.; Xia, Y.; Sun, Q. Study of localized deformation in geopolymer cemented coal gangue-fly ash backfill based on the digital speckle correlation method. Constr. Build. Mater. 2019, 215, 321-331. [CrossRef]

28. He, Y.; Chen, Q.; Qi, C.; Zhang, Q.; Xiao, C. Lithium slag and fly ash-based binder for cemented fine tailings backfill. J. Environ. Manag. 2019, 248, 109282. [CrossRef]

29. Katpady, D.N.; Takewaka, K.; Yamaguchi, T.; Akira, Y. Performance of slag based Shirasu geopolymer cured under ambient condition. Constr. Build. Mater. 2020, 234, 117210. [CrossRef]

30. Feng, Y.; Kero, J.; Yang, Q.; Chen, Q.; Engstrom, F.; Samuelsson, C.; Qi, C. Mechanical activation of granulated copper slag and its influence on hydration heat and compressive strength of blended cement. Materials 2019, 12, 772. [CrossRef]

31. Feng, Y.; Yang, Q.; Chen, Q.; Kero, J.; Andersson, A.; Ahmed, H.; Engström, F.; Samuelsson, C. Characterization and evaluation of the pozzolanic activity of granulated copper slag modified with CaO. J. Clean. Prod. 2019, 232, 1112-1120. [CrossRef]

32. Jiang, H.; Qi, Z.; Yilmaz, E.; Han, J.; Qiu, J.; Dong, C. Effectiveness of alkali-activated slag as alternative binder on workability and early age compressive strength of cemented paste backfills. Constr. Build. Mater. 2019, 218, 689-700. [CrossRef]

33. Jiang, H.; Mamadou, F.; Liang, C. Yield stress of cemented paste backfill in sub-zero environments: Experimental results. Miner. Eng. 2016, 92, 141-150.

34. Cihangir, F.; Akyol, Y. Mechanical, hydrological and microstructural assessment of the durability of cemented paste backfill containing alkali-activated slag. Int. J. Min. Reclam. Env. 2016, 32, 123-143. [CrossRef]

35. Cihangir, F.; Ercikdi, B.; Kesimal, A.; Turan, A.; Deveci, H. Utilisation of alkali-activated blast furnace slag in paste backfill of high-sulphide mill tailings: Effect of binder type and dosage. Miner. Eng. 2012, 30, $33-43$. [CrossRef]

36. Qiu, J.; Zhao, Y.; Xing, J.; Sun, X. Fly ash/blast furnace slag-based geopolymer as a potential binder for mine backfilling: effect of binder type and activator concentration. Adv. Mater. Sci. Eng. 2019, 2019, 2028109. [CrossRef]

37. Collins, F.; Sanjayan, J.G. Effects of ultra-fine materials on workability and strength of concrete containing alkali-activated slag as the binder. Cem. Concr. Res. 1999, 29, 459-462. [CrossRef]

38. Rostami, M.; Behfarnia, K. The effect of silica fume on durability of alkali activated slag concrete. Constr. Build. Mater. 2017, 134, 262-268. [CrossRef]

39. Ramezanianpour, A.A.; Moeini, M.A. Mechanical and durability properties of alkali activated slag coating mortars containing nanosilica and silica fume. Constr. Build. Mater. 2018, 163, 611-621. [CrossRef]

40. Rashad, A.M.; Khalil, M.H. A preliminary study of alkali-activated slag blended with silica fume under the effect of thermal loads and thermal shock cycles. Constr. Build. Mater. 2013, 40, 522-532. [CrossRef]

41. Wetzel, A.; Middendorf, B. Influence of silica fume on properties of fresh and hardened ultra-high performance concrete based on alkali-activated slag. Cem. Concr. Compos. 2019, 100, 53-59. [CrossRef] 
42. Alanazi, H.; Hu, J.; Kim, Y.-R. Effect of slag, silica fume, and metakaolin on properties and performance of alkali-activated fly ash cured at ambient temperature. Constr. Build. Mater. 2019, 197, 747-756. [CrossRef]

43. Ben Haha, M.; Le Saout, G.; Winnefeld, F.; Lothenbach, B. Influence of activator type on hydration kinetics, hydrate assemblage and microstructural development of alkali activated blast-furnace slags. Cem. Concr. Res. 2011, 41, 301-310. [CrossRef]

44. Feng, G.; Ren, Y.; Zhang, X.; Guo, Y.; Kang, L. The activating experimental research of fly ash for mining filling material in Tashan Mine. J. China Coal. Soc. 2011, 36, 732-737.

45. Freyburg, E.; Berninger, A.M. Field experiences in concrete deterioration by thaumasite formation: Possibilities and problems in thaumasite analysis. Cem. Concr. Compos. 2003, 25, 1105-1110. [CrossRef]

46. Ma, B.; Gao, X.; Byars, E.A.; Zhou, Q. Thaumasite formation in a tunnel of Bapanxia Dam in Western China. Cem. Concr. Res. 2006, 36, 716-722. [CrossRef]

47. Gatta, G.D.; McIntyre, G.J.; Swanson, J.G.; Jacobsen, S.D. Minerals in cement chemistry: A single-crystal neutron diffraction and Raman spectroscopic study of thaumasite, $\mathrm{Ca}_{3} \mathrm{Si}(\mathrm{OH})_{6}\left(\mathrm{CO}_{3}\right)\left(\mathrm{SO}_{4}\right) \cdot 12 \mathrm{H}_{2} \mathrm{O}$. Am. Mineral. 2012, 97, 1060-1069. [CrossRef]

48. Bensted, J. Thaumasite-direct, woodfordite and other possible formation routes. Cem. Concr. Compos. 2003, 25, 873-877. [CrossRef]

49. van Hees, R.P.J.; Wijffels, T.J.; van der Klugt, L.J.A.R. Thaumasite swelling in historic mortars: Field observations and laboratory research. Cem. Concr. Compos. 2003, 25, 1165-1171. [CrossRef]

(C) 2020 by the authors. Licensee MDPI, Basel, Switzerland. This article is an open access article distributed under the terms and conditions of the Creative Commons Attribution (CC BY) license (http://creativecommons.org/licenses/by/4.0/). 